\title{
New Combinations in Schoenoplectus (Cyperaceae) from China
}

\author{
Song-Yun Liang and Shu-Ren Zhang* \\ State Key Laboratory of Systematic and Evolutionary Botany, Institute of Botany, \\ Chinese Academy of Sciences, Beijing 100093, People's Republic of China. \\ *Author for correspondence: srzhang@ibcas.ac.cn
}

Abstract. Five new combinations in Schoenoplectus (Rchb.) Palla (Cyperaceae) are proposed for taxa occurring in China. All these taxa previously had been placed in Scirpus L. s.l., which has been split into segregate genera in the recent literature. The following transfers are made for taxa originally described from China: Schoenoplectus chuanus (Tang \& F. T. Wang) S. Yun Liang \& S. R. Zhang, its type from Jiangsu; S. jünmenensis (Tang \& F. T. Wang) S. Yun Liang \& S. R. Zhang, from Hubei; S. monocephalus (J. Q. He) S. Yun Liang \& S. R. Zhang, from Anhui; S. pseudoarticulatus (L. K. Dai \& S. M. Huang) S. Yun Liang \& S. R. Zhang, from Hainan; and $S$. supinus (L.) Palla subsp. densicorrugatus (Tang \& F. T. Wang) S. Yun Liang \& S. R. Zhang, from Xinjiang.

Key words: China, Cyperaceae, Schoenoplectus, Scirpus.

The genus Scirpus L. (Cyperaceae) has been demonstrated to be heterogeneous, and it has been split into segregate genera (Wilson, 1981; Haines \& Lye, 1983; Zhan \& Yang, 1987a, b, c; Bruhl, 1995; Goetghebeur, 1998; Kukkonen, 1998; Muasya et al., 1998, 2000, 2001; Smith \& Hayasaka, 2001, 2002; Pignotti \& Mariotti, 2004). Although previously treated as a single genus in Flora Reipublicae Popularis Sinicae (Tang \& Wang, 1961), Chinese Scirpus s.l. segregates into the six genera Actinoscirpus (Ohwi) R. W. Haines \& Lye, Bolboschoenus (Asch.) Palla, Isolepis R. Br., Schoenoplectus (Rchb.) Palla, Scirpus, and Trichophorum Pers. This follows the scheme of Goetghebeur's 1998 classification and will correspond to our treatment of the Cyperaceae for the Flora of China.

Accordingly, five taxa from Scirpus s.l. distributed in China are transferred here into Schoenoplectus as new combinations. Four of these taxa (Scirpus chuanus Tang \& F. T. Wang, S. jüngmenensis Tang \& F. T. Wang, $S$. monocephalus J. Q. He, and S. pseudoarticulatis L. K. Dai \& S. M. Huang) were previously considered in Scirpus but are all characterized by a group of morphological traits (stolon presence, tuber presence, nodeless culms, culm-like bracts, and pseudolateral inflorescences) that currently delimit Schoenoplectus (Wilson, 1981; Smith \& Hayasaka, 2001).

Novon 20: 170-171. Published on 9 June 2010.
1. Schoenoplectus chuanus (Tang \& F. T. Wang) S. Yun Liang \& S. R. Zhang, comb. nov. Basionym: Scirpus chuanus Tang \& F. T. Wang, Fl. Reipubl. Popularis Sin. 11: 222. 1961. TYPE: China. Jiangsu: Nanjing, watery places, 17 Aug. 1931, K. L. Chu 341 (holotype, PE).

Distribution. Schoenoplectus chuanus is only known from Jiangsu, China.

Specimen examined. CHINA. Jiangsu: Jurong, M. B. Deng 3640 (PE).

2. Schoenoplectus jingmenensis (Tang \& F. T. Wang) S. Yun Liang \& S. R. Zhang, comb. nov. Basionym: Scirpus jingmenensis Tang \& F. T. Wang, Fl. Reipubl. Popularis Sin. 11: 222. 1961. TYPE: China. Hubei: Jingmen, 27 Sep. 1940, H. Migo s.n. (holotype, PE).

Distribution. Schoenoplectus jingmenensis is only known from Hubei, China.

Specimen examined. CHINA. Hubei: Jingmen, s.d., H. Migo s.n. (PE).

3. Schoenoplectus monocephalus (J. Q. He) S. Yun Liang \& S. R. Zhang, comb. nov. Basionym: Scirpus monocephalus J. Q. He, Acta Phytotax. Sin. 37(3): 291, f. 1. 1999. TYPE: China. Anhui: Fuyang, riversides, 8 June 1994, J. Q. He \& X. L. Hou 5438 (holotype, Herbarium of Resources Plants, Anhui University not seen).

Distribution. Schoenoplectus monocephalus is only known from Anhui, China.

Specimen examined. CHINA. Anhui: Fuyang, J. Q. He 5493 (PE).

4. Schoenoplectus pseudoarticulatus (L. K. Dai \& S. M. Huang) S. Yun Liang \& S. R. Zhang, comb. nov. Basionym: Scirpus pseudoarticulatus L. K. Dai \& S. M. Huang, Fl. Hainan. 4: 538. 1977. TYPE: China. Hainan: Yiaxian, 19-29 May 1935, S. K. Lau 5746 (holotype, IBSC).

doi: $10.3417 / 2009034$ 
Distribution. Schoenoplectus pseudoarticulatus is known from Hainan, China, and also occurs in India. No specimens other than the type were seen, and the distributional information is taken from Flora Hainanica (Anonymous, 1977).

5. Schoenoplectus supinus (L.) Palla, Bot. Jahrb. Syst. 10: 299. 1888. Basionym: Scirpus supinus L., Sp. Pl. 1: 49. 1753. TYPE: France. Paris: Hb. Tournefort 5117 (neotype, designated by Raynal, 1976: 145, P-TRF not seen).

\section{5a. Schoenoplectus supinus subsp. supinus.}

Distribution. Schoenoplectus supinus subsp. supinus is distributed in Europe, North Africa, Turkey, the Caucasus, southern Siberia, Kazakhstan, Iran, Pakistan, and East Asia, but is not found in China.

Discussion. Subspecies supinus is characterized by its larger spikes (5-12 $\mathrm{mm}$ ) and the conspicuously transversely rugulose nut surface.

5b. Schoenoplectus supinus subsp. densicorrugatus (Tang \& F. T. Wang) S. Yun Liang \& S. R. Zhang, comb. et stat. nov. Basionym: Scirpus supinus var. densicorrugatus Tang \& F. T. Wang, Fl. Reipubl. Popularis Sin. 11: 223. 1961. TYPE: China. Xinjiang: s. loc., 7 Sep. 1956, R. C. Ching 786 (holotype, PE).

Distribution. Schoenoplectus supinus subsp. densicorrugatus is only known from Xinjiang, China.

Discussion. There are several infraspecific taxa within Schoenoplectus supinus, but only two occur in China: S. supinus subsp. lateriflorus (J. F. Gmel.) Soják and $S$. supinus subsp. densicorrugatus. The latter was originally described at varietal rank, differing from subspecies supinus by its smaller spikes (3-6 mm) and more densely and finely rugulose nut surface. The rank of subspecies is applied here in order to be consistent with taxonomic precedence otherwise recognized within the species.

Specimens examined. CHINA. Xinjiang: s. loc., R. C. Ching 786 (PE).

Acknowledgments. This study was supported by the National Natural Science Foundation of China (grant no. 30670149).

\section{Literature Cited}

Anonymous. 1977. Scirpus. Pp. 274-278 in Flora Hainanica, Vol. IV. Science Press, Beijing.

Bruhl, J. J. 1995. Sedge genera of the world: Relationships and a new classification of the Cyperaceae. Austral. Syst. Bot. 8: 125-305.

Goetghebeur, P. 1998. Cyperaceae. Pp. 141-190 in F. Kubitzki, H. Huber, P. J. Rudall, P. S. Stevens \& T. Stützel (editors), The Families and Genera of Vascular Plants, Vol. 4. Springer-Verlag, Berlin.

Haines, R. W. \& K. A. Lye. 1983. The Sedges and Rushes of South Africa. African Natural History Society, Nairobi.

Kukkonen, I. 1998. Cyperaceae. P. 173 in M. Assadi, M. Kathansaz, A. A. Maassoumi \& V. Mozaffarian (editors), Flora Iranica. Ministry of Agriculture, Tehran.

Muasya, A. M., D. A. Simpson, M. W. Chase \& A. Culham. 1998. An assessment of suprageneric phylogeny in Cyperaceae using $r b c \mathrm{~L}$ DNA sequences. Pl. Syst. Evol. 211: 257-271.

$-\longrightarrow,-$ — $\longrightarrow$. 2000. Phylogenetic relationships within the heterogeneous Scirpus s.l. (Cyperaceae) inferred from $r b c \mathrm{~L}$ and $t r n \mathrm{~L}-\mathrm{F}$ sequence data. Pp. 610-614 in K. L. Wilson \& D. A. Morrison (editors), Monocots: Systematics and Evolution. CSIRO, Melbourne.

— $—$ \& 2001. A phylogeny of Isolepis (Cyperaceae) inferred using plastid $r b c \mathrm{~L}$ and $t r n \mathrm{~L}-\mathrm{F}$ sequences data. Syst. Bot. 26: 342-353.

Pignotti, L. \& L. M. Mariotti. 2004. Micromorphology of Scirpus (Cyperaceae) and related genera in south-west Europe. Bot. J. Linn. Soc. 145: 45-58.

Raynal, J. 1976. Notes cyperologiques: 26. Le genere Schoenoplectus. II. L'amphicarpie et la sect. Supini. Adansonia, n.s. 16(1): 119-155.

Smith, S. G. \& E. Hayasaka. 2001. Delineation of Schoenoplectus sect. Malacogeton (Cyperaceae), new combination, and distinctions of species. J. Jap. Bot. 76: 339-343.

— \& 2002. New combinations within North American Schoenoplectus smithii and S. purshianus (sect. Actaeogeton, Cyperaceae) and comparison with eastern Asian allies. Novon 12: 106-111.

Tang, T. \& F. T. Wang. 1961. Flora Reipublicae Popularis Sinicae, Vol. 11. Science Press, Beijing.

Wilson, K. L. 1981. A synopsis of the genus Scirpus sens. lat. (Cyperaceae) in Australia. Telopea 2: 153-172.

Zhan, M. \& Y. C. Yang. 1987a. Studies on the genus Scirpus L. (s.l.) in northwestern China I. The anatomy of leaf blade with a discussion of its taxonomy. Acta Biol. Plateau Sin. 6: 247-258.

— 1 1987b. Studies on the genus Scirpus L. (s.l.) in northwestern China II. The morphology of the mature embryo and pollen. Acta Biol. Plateau Sin. 7: $1-10$.

. 1987c. Studies on the genus Scirpus L. (s.l.) in northwestern China III. Systematic classification. Acta Biol. Plateau Sin. 7: 11-26. 


\section{$2 \mathrm{BHL}$ Biodiversity Heritage Library}

Liang, Songyun. and Zhang, Shu Ren. 2010. "New Combinations in Schoenoplectus (Cyperaceae) from China." Novon a journal of botanical nomenclature from the Missouri Botanical Garden 20, 170-171.

View This Item Online: https://www.biodiversitylibrary.org/item/123332

Permalink: https://www.biodiversitylibrary.org/partpdf/122002

\section{Holding Institution}

Missouri Botanical Garden, Peter H. Raven Library

\section{Sponsored by}

Missouri Botanical Garden

\section{Copyright \& Reuse}

Copyright Status: Permission to digitize granted by rights holder Rights: https://www.biodiversitylibrary.org/permissions

This document was created from content at the Biodiversity Heritage Library, the world's largest open access digital library for biodiversity literature and archives. Visit BHL at https://www.biodiversitylibrary.org. 